\title{
Influence of the Airflow in a Solar Passive Building on the Indoor Air Quality and Thermal Comfort Levels
}

\author{
Eusébio Conceição ${ }^{1,2, * \mathbb{D}}$, João Gomes ${ }^{2}$ and Hazim Awbi ${ }^{3}$ \\ 1 FCT-Universidade do Algarve, Campus de Gambelas, 8005-139 Faro, Portugal \\ 2 CINTAL, Campus de Gambelas, 8005-139 Faro, Portugal; jgomes@ualg.pt \\ 3 School of Built Environment, University of Reading, Reading RG6 6AW, UK; h.b.awbi@reading.ac.uk \\ * Correspondence: econcei@ualg.pt; Tel.: +351-289-800-900
}

Received: 21 October 2019; Accepted: 28 November 2019; Published: 2 December 2019

\begin{abstract}
The influence of the airflow in a solar passive building on the indoor air quality and thermal comfort levels was investigated. The numerical study for a university library was conducted using a software that simulates the building thermal behavior with complex topology, in transient conditions, for evaluating the indoor air quality and occupants' thermal comfort levels for typical summer and winter days. Solar radiation was used as a renewable energy source to increase simultaneously the thermal comfort and air quality levels and reduce building energy consumption. Regarding the solar passive building, consideration was given to all of the building structure envelope, shading devices and interior details, while in the solar active building active ventilation was used. To analyze the airflow that simultaneously provides the best indoor air quality and thermal comfort levels, a new integral methodology based on the minimization of the total number of uncomfortable hours was used. The results show that it was possible to determine an air change rate that ensures a good compromise between thermal comfort and indoor air quality. An optimal air change rate of two and three renewals per hour had been determined, respectively, for winter and summer conditions.
\end{abstract}

Keywords: building; thermal comfort; indoor air quality; solar radiation; cross ventilation

\section{Introduction}

Today, climate change is considered one of the biggest challenges humanity is facing. Its size and effects are unquestionable, they are well diagnosed and monitored, and have been closely followed by the scientific community for a long time. Greenhouse gas emissions have increased leading to global warming and, consequently, the last 17 years have seen the highest temperatures [1].

The International Energy Agency reports that energy production and consumption contribute to most of greenhouse gas emissions, particularly carbon dioxide $\left(\mathrm{CO}_{2}\right)$, which is considered to be the leading cause of global warming [2]. The building sector accounts for approximately $40 \%$ of global energy consumption [3], and 30\% of $\mathrm{CO}_{2}$ emissions [4]. However, it is recognized that the building sector has great potential to reduce its energy consumption by implementing measures to improve its energy efficiency $[5,6]$.

Implementing energy efficiency measures in the construction of new buildings or the rehabilitation of existing ones, or solutions to achieve Near/Nearly-Zero Energy Buildings, is essential to minimize the impacts of climate change and achieve a sustainable environment [7-10]. Thus, the implementation of measures to improve the energy efficiency of buildings, as well as providing an opportunity to improve their thermal and energy performance, is a strategy for mitigation and adaptation to the effects of climate change [11-14].

Buildings contribute a high share of the environmental, economic and social impacts in the world today, mainly due to the consumption of natural resources (fossil energy, water, raw materials, among others), the unregulated and excessive land use, external air pollution, water pollution and indoor 
environment pollution [15]. To address these negative impacts, a new paradigm has emerged among the players in the construction industry and the building sector: the concept of green buildings (also known as a sustainable or high performance building [16]). This concept has many definitions, the most consensual being that of the US Environmental Protection Agency, which states that: "green building is the practice of creating structures and using processes that are environmentally responsible and resource-efficient throughout a building's life-cycle from siting to design, construction, operation, maintenance, renovation and deconstruction" [16].

Recently, there has been a large development of green buildings and their implementation is increasingly widespread in many countries [5]. An extensive review of this development can be found in Ahmad et al. [7]. To promote the green building development and evaluate their implementation and performance, there was a need to create rating systems or tools to assess and certify these kinds of buildings. These systems are very diverse and dependent on the countries where they are implemented [6,14,17-19]. Chethana et al. [8], after analyzing and comparing the different rating systems presented in the existing literature, concluded that the three most widely considered key credit criteria are energy, indoor environment quality and water, in this order. A review study on the operating performance of green buildings showed that the energy performance is better and the occupants' satisfaction level is higher in green buildings than in conventional buildings [19]. However, greater government intervention is needed for the promotion of green buildings, with a better incentive policy directed at building owners [20].

One of the most important challenges of green buildings is simultaneously to reduce energy consumption and improve indoor air quality, maintaining the occupant's thermal comfort level within acceptable standards. The study by Persily and Emmerich [11] proposes some strategies to achieve these goals, namely increased envelope air tightness, heat recovery ventilation, demand controlled ventilation, and improved operations and maintenance, among others. Since $40 \%$ and $15 \%$ of the energy consumed in a building are, respectively, by Heating, Ventilating and Air Conditioning (HVAC) systems and lighting, some authors propose to reduce this energy by integrated control of active and passive sources of heating, cooling, lighting, shading and ventilation $[13,21]$.

Thermal comfort studies of school buildings have been made over the years due to their importance (see [22-25] for example). These kinds of studies have been made in many countries throughout the world, considering different climates and HVAC systems.

The traditional comfort indexes, such as PMV (Predicted Mean Vote) and PPD (Predicted Percentage of Dissatisfied), developed by Fanger [26], and adopted by international standards like ISO 7730 [27], and ASHRAE (American Society of Heating, Refrigerating and Air-Conditioning Engineers) Standard 55 [28], are appropriate in spaces equipped with HVAC systems.

According to ISO 7730 [27], and ASHRAE Standard 55 [28], the sensation of thermal comfort can be defined as "that condition of mind that expresses satisfaction with the thermal environment", that is, the person is thermally comfortable in a certain indoor environment when he or she does not feel cold or hot. This definition assumes a certain degree of individual subjectivity, associated with the physical aspects (thermal environment) and the subjective intrinsic physiological and psychological aspects of the occupant [26]. Thus, it is difficult to achieve thermal comfort conditions in a space that satisfies all its occupants. Moreover, one must take into account the adaptation that a person experiences when entering a space from another with different thermal comfort requirements [28].

The use of natural and hybrid ventilation strategies can make the building more environmentally sustainable and more energy efficient $[29,30]$. Natural ventilation, when used in the summer season as a passive cooling process, offers efficient ways of reducing the energy consumption of buildings while maintaining acceptable indoor thermal comfort conditions $[29,31]$. The efficiency of this process depends on the location and design of the buildings $[29,32,33]$ and the natural ventilation strategies used [31,34,35]. The use of cross-ventilation for controlling airflow in and around a building, the opening of windows and drawing of blinds or curtains, and the automatic or manual control of the openings are examples of such strategies. The contribution of some of these strategies to achieving adequate 
thermal comfort levels can be seen in Gallardo et al. [36] for temperate climates and in Conceição et al. $[37,38]$ for Mediterranean-type climates.

It is very hard to provide thermal comfort during a building's entire period of occupation. This issue should be addressed under the consideration of long-term thermal comfort for economic and environmental reasons. To evaluate the long-term thermal comfort conditions, concepts such as warm and cold uncomfortable hours are introduced in the literature $[27,39,40]$. This methodology considers the time that the PMV index exceeds the limits previously set as acceptable.

Indoor pollution sources that release gases or particles into the air are the primary cause of indoor air quality problems in buildings [41]. Inadequate ventilation can increase indoor pollutant levels if it cannot provide fresh outside air to dilute emissions from indoor sources and cannot remove indoor air pollutants to outside the building [42,43]. High temperature and humidity levels also can increase concentrations of some pollutants [44]. Concentration of outdoor pollutants also affect indoor air quality [44]. Therefore, the type and efficiency of the ventilation system used influences the condition in which outdoor air enters buildings and the maintenance of indoor air quality within acceptable limits [45].

Regarding some situations, measurements of indoor $\mathrm{CO}_{2}$ concentrations can be used to assess indoor air quality and ventilation performance $[44,46,47]$. The relationship between $\mathrm{CO}_{2}$ concentration and the ventilation rate, under steady-state conditions, is presented in ASHRAE Standard 62.1 [48], which also provides an equation that allows us to estimate the $\mathrm{CO}_{2}$ generation rates in $\mathrm{L} / \mathrm{s}$ per person. This is dependent on the metabolic rate, the respiratory level, the height and body mass of the person, as shown by Persily and de Jonge [49]. Normally, an indicator of an acceptable indoor air quality is a $\mathrm{CO}_{2}$ concentration below 1000 ppm [48]. However, associations between $\mathrm{CO}_{2}$ concentrations and occupant perceptions of the indoor environment are more complex because they combine several issues including the comfort impacts of $\mathrm{CO}_{2}$ itself, associations between the $\mathrm{CO}_{2}$ concentrations and other contaminants, and the relationship between $\mathrm{CO}_{2}$ and ventilation [50].

Measures to minimize the energy consumption of buildings include the use of solar energy as a renewable source of energy [51], and building design utilizing passive strategies [52]. Furthermore, there are techniques that can be implemented during the building design using solar technologies to obtain an energy efficient passive solar building $[53,54]$. Among these measures, optimizing the shape of the building and its correct orientation can save over 35\% in energy requirements for space heating [55]. Properly designed shading devices must be used to avoid excessive exposure to solar radiation for interior spaces, with a strategy of optimizing the building envelope, namely the window-wall ratio [56]. The enclosure must be constructed with high performance thermal insulation materials and ensuring its good tightness [54]. Solar chimneys, thermal storage walls and Trombe walls are good examples of the solar technologies that can be used [57].

The purpose of this paper is to analyze the influence of the airflow in a solar passive building on the indoor air quality and thermal comfort levels under low building energy consumption conditions. The required air change rate will be obtained using cross-ventilation techniques, taking advantage of the passive characteristics of the building and its exposure to solar radiation. To obtain the airflow that simultaneously guarantees the best air quality and thermal comfort levels a new methodology that considers an integral model based on the minimization of the total number of uncomfortable hours due to warm and cold conditions, as well as indoor air quality, is applied. To calculate the uncomfortable hours due to air quality, a new methodology also is used which is based on the number of hours that the level of $\mathrm{CO}_{2}$ concentration is above $1000 \mathrm{ppm}$. This study is based on numerical analysis using a building thermal behavior software developed by the authors.

\section{Methods}

\subsection{PMV and PPD Models}

Fanger's model combines the heat balance principle with the thermoregulation physiology theory to determine a range of temperatures at which building occupants will feel thermally comfortable [28]. 
According to these theories, the human body uses physiological processes (e.g., sweating, shivering, regulating blood flow to the skin) to maintain a balance between the heat produced by metabolism and the heat lost by the human body. Maintaining this heat balance is the first condition for achieving neutral thermal sensation. To be able to predict conditions where thermal neutrality will occur, Fanger investigated the physiological processes of the human body when it is under thermally neutral conditions [26]. Fanger determined that sweat rate and mean skin temperature are the only physiological processes that influence the heat balance and they are dependent on the activity level and clothing level. The resulting Fanger equation described thermal comfort as the imbalance between the actual heat flow from the human body in a given thermal environment and a heat flow required to achieve optimum (neutral) thermal comfort when a given activity is performed [28].

The PMV index model is a combination of four physical variables, namely: the indoor air temperature, the indoor air velocity, the indoor air relative humidity and the mean radiant temperature, and two personal variables, namely: the clothing insulation level and the activity level [27]. The PMV index is used to define the thermal comfort requirements for the occupied spaces according to the 3 comfort categories given in ASHRAE 55 and ISO 7730 standards: category A $(-0.2 \leq$ PMV $\leq+0.2)$, category B $(-0.5 \leq \mathrm{PMV} \leq+0.5)$ and category $\mathrm{C}(-0.7 \leq \mathrm{PMV} \leq+0.7)[27,28]$. The PPD index as a percentage, is related to the PMV index as given in ISO 7730 [27].

When the PMV index is equal to zero there are still some individual cases of dissatisfaction. This is due to some differences of sensation in the thermal comfort perception from one person to another. Regarding this, it is assumed that the PPD index is equal to $5 \%$.

Here, the PMV index within category C (PPD $\leq 15 \%$ ) was used as the thermal comfort requirement in accordance with the ISO 7730 [27] and the AHSRAE 55 [28] standards. This category was appropriate to the moderate Mediterranean-type climate where the studied building was located, as seen in previous works developed for buildings with complex topology located in the same region $[38,58,59]$.

\subsection{Long-Term Thermal Comfort Models}

The concepts of warm and cold uncomfortable hours are introduced by Olesen and Parsons [39] and Van der Linden et al. [40]. This allows comparing situations with different levels of thermal discomfort over a long period of occupation time. To evaluate the long-term thermal comfort conditions, the ISO 7730 standard presents the following parameters [27]:

- Warm Uncomfortable Hours (WUH), which is given by the following equation:

$$
\mathrm{WUH}=\sum_{\mathrm{i}}\left(\frac{\mathrm{PPD}_{\mathrm{i}}}{\mathrm{PPD}_{\lim }}\right) \Delta \mathrm{t}_{\mathrm{i}} \quad \text { for } \quad \mathrm{PMV}_{\mathrm{i}}>\mathrm{PMV}_{\mathrm{lim}}
$$

- Cold Uncomfortable Hours (CUH), which is given by the following equation:

$$
\mathrm{CUH}=\sum_{\mathrm{i}}\left(\frac{\mathrm{PPD}_{\mathrm{i}}}{\operatorname{PPD}_{\lim }}\right) \Delta \mathrm{t}_{\mathrm{i}} \quad \text { for } \quad \mathrm{PMV}_{\mathrm{i}}<\mathrm{PMV}_{\text {lim }}
$$

The sub-index (i) is associated to a time interval $\left(\Delta \mathrm{t}_{\mathrm{i}}\right)$ and the sub-index (lim) is associated to the PMV and PPD acceptable range limits. This methodology considers the time that the PMV exceeds the defined limits of acceptable range.

Here, the PMV index limits were +0.7 and -0.7 , respectively, for summer and winter conditions. Thus, the PPD index limit was 15\%. 


\subsection{Long-Term Indoor Air Quality Model}

Considering a methodology similar to that presented for long-term thermal comfort, this paper proposes a new methodology to consider that the number of uncomfortable hours due to indoor air quality can be defined by the following equation:

$$
\mathrm{AQUH}=\sum_{\mathrm{i}}\left(\frac{\mathrm{PD}_{\mathrm{i}}}{\mathrm{PD}_{\lim }}\right) \Delta \mathrm{t}_{\mathrm{i}} \quad \text { for } \quad \mathrm{PD}_{\mathrm{i}}>\mathrm{PD}_{\lim }
$$

where AQUH represents the Air Quality Uncomfortable Hours, PD represents the predicted percentage of people dissatisfied with indoor air quality, based on $\mathrm{CO}_{2}$ concentration, which is evaluated according to ASHRAE 62.1 standards [48]; the sub-index (i) is associated to a time interval $\left(\Delta \mathrm{t}_{\mathrm{i}}\right)$; $P \mathrm{D}_{\text {lim }}$ is the admissible limit for the predicted dissatisfied people (26.7\%) for an admissible $\mathrm{CO}_{2}$ concentration limit of $1000 \mathrm{ppm}$.

\subsection{Long-Term Integral Model}

The long-term integral model can be used to evaluate the total number of uncomfortable hours (UH) over a long period of occupation time due to both thermal and indoor air quality conditions. The airflow that simultaneously provides the best indoor air quality and thermal comfort levels is obtained through this new integral methodology based on the minimization of the total number of uncomfortable hours. The total number of uncomfortable hours is obtained using the sum of the warm uncomfortable hours (WUH), the cold uncomfortable hours (CUH) and the uncomfortable hours due to indoor air quality (AQUH):

$$
\mathrm{UH}=\mathrm{WUH}+\mathrm{CUH}+\mathrm{AQUH}
$$

\subsection{Numerical Model of Building Thermal Beahviour}

Here, a building thermal behavior software developed by the authors was used [59]. This numerical model that simulates the thermal response of a building with complex topology was based on energy and mass balance integral equations and worked under transient conditions. Considering the generation of the energy and mass balance integral equations the building geometry was used. These equations were solved by the Runge-Kutta-Felberg method with error control.

The energy balance integral equations were developed for the interior spaces, opaque main bodies, transparent bodies and interior bodies. These equations were based on conduction, convection, radiation and evaporation concepts. All coefficients used in these equations were evaluated by a sub-model that calculated the incident solar radiation, internal view factors, radiative heat exchanges, glass radiative properties, occupation cycles, ventilation strategies, human thermo-physiology and convective heat and mass transfer coefficients using empirical expressions.

The building's main bodies (doors, ceiling, ground, walls, etc.) were divided into several layers. The conduction was considered between the layers in contact.

The natural, forced and mixed heat transfer phenomena were considered in the convection model. The convection was considered between the building's main layers and transparent surfaces in contact with the indoor and outdoor environment. Regarding the natural, forced and mixed convection, dimensionless coefficients, with empirical expressions, were used. Concerning the natural convection, the indoor and outdoor temperature fields were considered, while in the forced convection the air velocity field was used. Vis-a-vis the indoor environment, the air recirculation and the air change rate were considered, while in the outdoor environment the wind speed and the wind direction were used.

The related inside and outside building surfaces, the short-wave and long-wave radiation were considered in the radiation model. Regarding the short-wave radiation, the real distribution of direct solar radiation for external and internal surfaces were considered; while for the long-wave radiation the heat exchanges between the building's external surfaces and the surrounding internal surfaces of 
each compartment were considered. The shading effect caused by the surrounding surfaces and by the internal surfaces was considered in these calculations.

The reflection, absorption and transmission coefficients in the transparent surfaces (glasses) were calculated by the numerical model as a function of the direction and intensity of the solar radiation. These values were calculated instantaneously during the simulation. Radiation transmission was considered to be the solar radiation that entered the transparent surface and incident to the internal transparent and other surfaces.

The mass balance integral equations were developed for the water vapour inside the building spaces, the contaminants inside the building spaces, the water vapour in the solid object for the main body of the building and interior bodies, the contaminants in the solid objects for the main body of the building and interior bodies, the water vapour on the main surfaces of the building, the interior bodies and windows glasses and the contaminants on the surface of the building's main bodies and interior bodies.

The water vapor and contaminant concentration on each space, for example, were calculated by applying the mass balance integral equations, in transient conditions, to each of the spaces. These equations considered the air change rate between the different spaces.

Since the $\mathrm{CO}_{2}$ concentration is a good indicator of indoor air pollution in occupied spaces $[37,44,60]$, it was used to evaluate the indoor air quality in the studied building. Following the ASHRAE 62.1 standard [48], the $\mathrm{CO}_{2}$ generation rate was a function of the physical activity level of the occupants. The numerical model only considered the $\mathrm{CO}_{2}$ generated by the occupants to account for the uncomfortable hours due to indoor air quality. However, in the numerical simulation, the materials adsorption and desorption, in transient conditions, were considered.

The building thermal behaviour numerical model was validated for a school environment in winter conditions [61], and in summer conditions [62]. Concerning both studies, the air temperature values calculated by the numerical model and experimental data measured inside the occupied spaces, were compared. Other details of the numerical model and other applications can be found in these studies [58,59,63-65]. Regarding this numerical simulation, only the passive and active solar resources were used.

\subsection{Description of the Studied Building}

The studied building is a modern library located at the University of Algarve campus, southern Portugal, set in a Mediterranean-type climate. It is a large building and comprised of three floors covering an area of about $8834 \mathrm{~m}^{2}$ (see Figure 1). This building was used due to its solar passive design characteristics. The architecture of the library was designed to encourage and take advantage of solar radiation, particularly for indoor natural lighting. It also has special shading devices designed to promote acceptable thermal comfort levels, either in summer or in winter conditions, using natural resources.

The South, East, North and West building facades has a glazed area of $307 \mathrm{~m}^{2}, 215 \mathrm{~m}^{2}, 253 \mathrm{~m}^{2}$ and $187 \mathrm{~m}^{2}$, respectively. The summits present on the roof has a glazed area of $490 \mathrm{~m}^{2}$. The interior walls are made of simple brick.

The building envelope is made of double brick walls separated by a thick air gap. The roof consisted of reinforced concrete slabs. The thickness of the outer windows is $4 \mathrm{~mm}$.

This library consists of 3 floors and a total of 134 compartments: a basement (Figure 2a), a ground floor (Figure 2b) and a first floor (Figure 2c).

The basement of the building consists of 33 compartments used to store or file books, cleaning utilities, a zone intended for machines, bathrooms, a car parking area and some offices. The areas of movement also were considered.

The main entrance of the building is located on the ground floor. This floor consists of a lobby and, in its environs, several cabinets for staff, utility areas, reading rooms, a bookstore, a copy room, a kitchen and WC, totalling 57 compartments. Compartment 52, in Figure 2, represents the main lobby of the library, which is used mainly for reading. The surrounding smaller compartments are offices. 
The first floor has compartments suitable for individual or group study, a seminar room, a meeting room, two photocopying rooms, several sanitary facilities, cleaning utilities, and cabinets for employees, with 44 compartments in total.

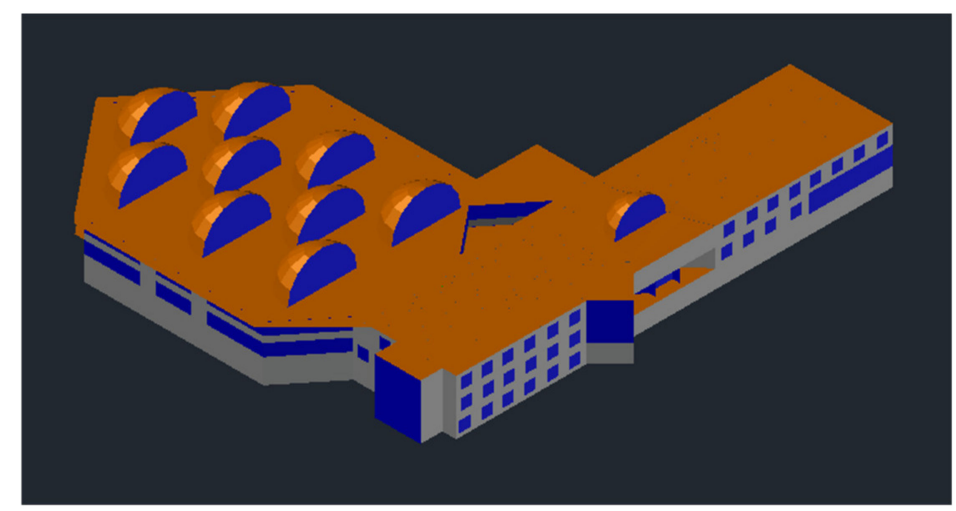

(a)

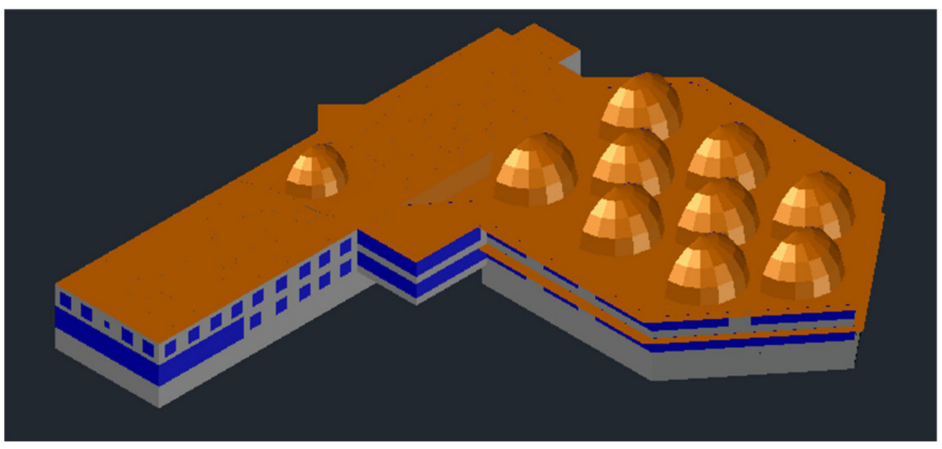

(b)

Figure 1. 3D library visualization: (a) Northeast view; (b) Southwest view. Blue color is associated with glasses, gray color is associated with walls and orange color is associated with roof and plates.

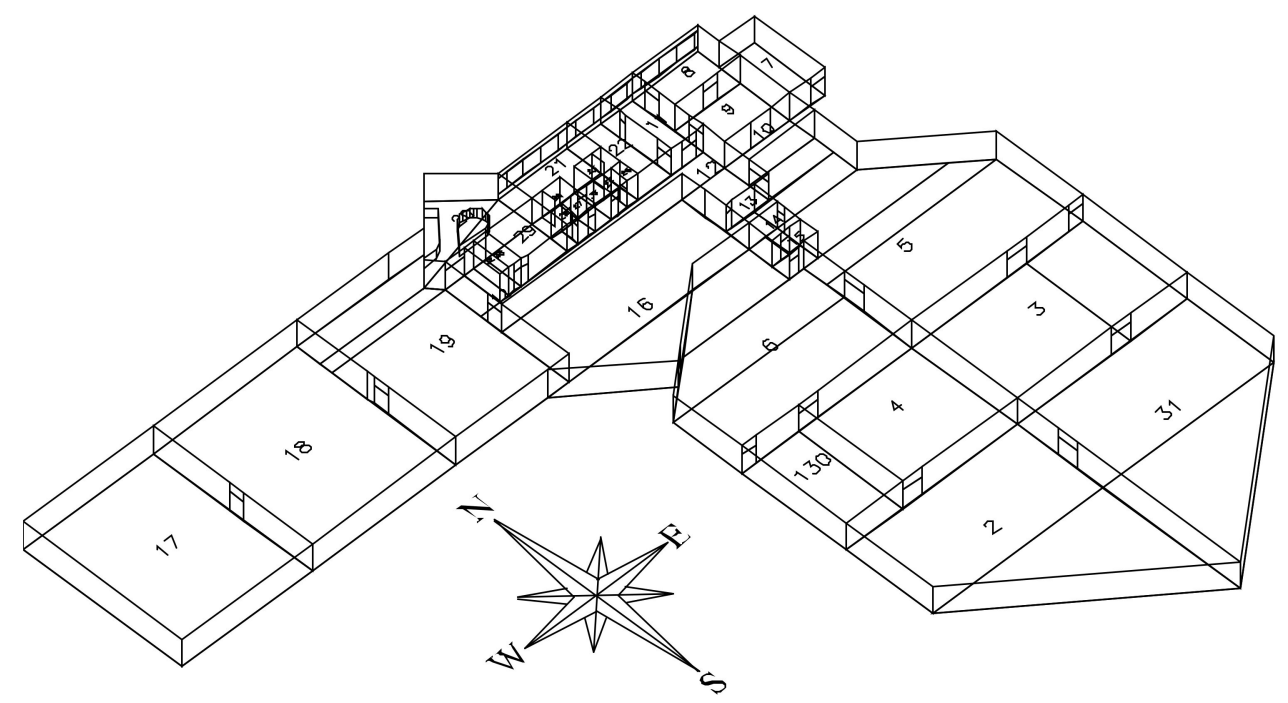

(a)

Figure 2. Cont. 


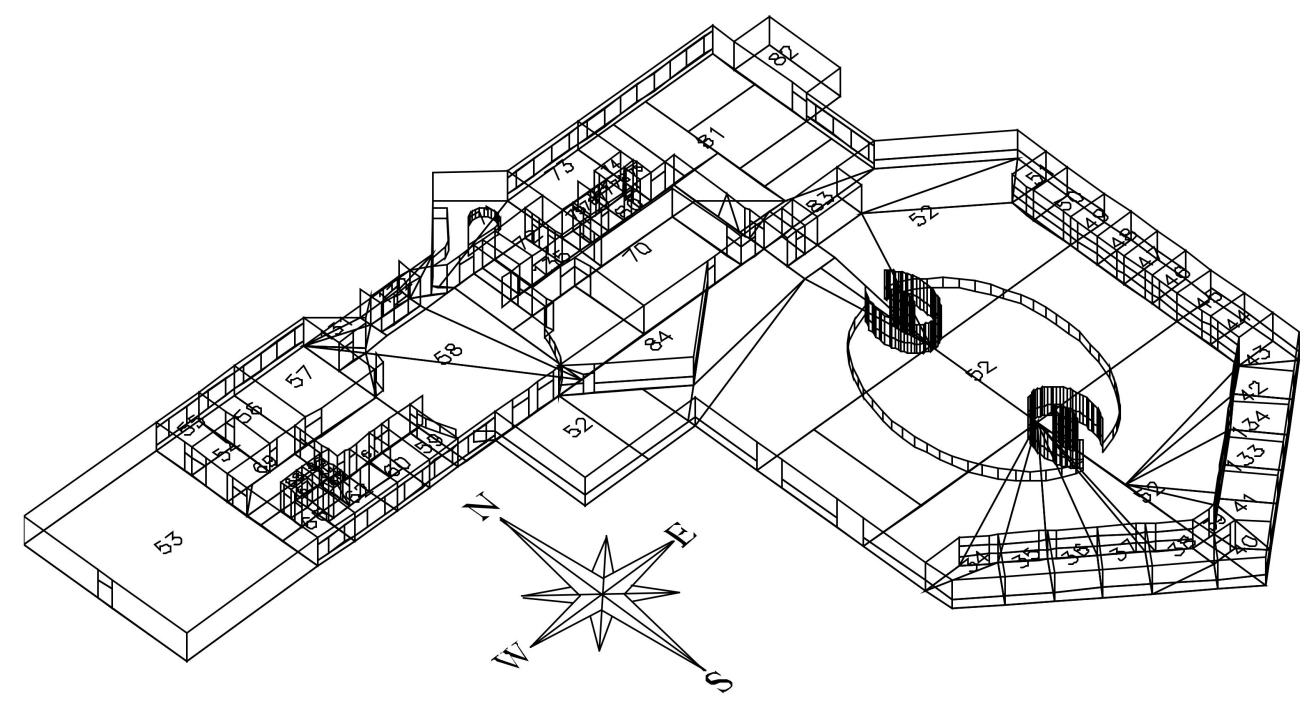

(b)

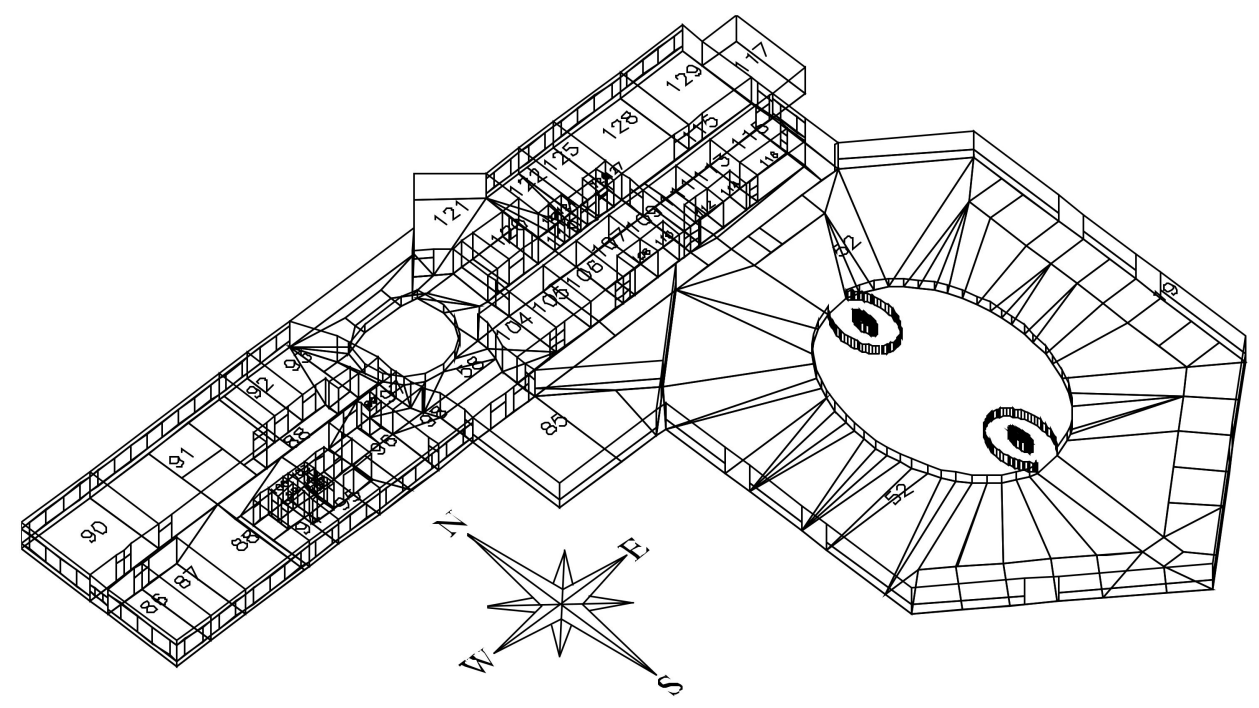

(c)

Figure 2. 3D visualization of the compartments' numeration: (a) basement; (b) ground floor; (c) first floor.

\subsection{Input Data of the Building Thermal Behaviour Numerical Model}

This study was conducted for a typical summer month (July) and a typical winter month (December) in the region. The meteorological input data used in the building thermal behaviour numerical model were the external air temperature, the external air relative humidity, the wind speed and the wind direction. The meteorological data used as reference, considered between 0 and 24 hours, were those referring to a typical summer day and a typical winter day in the region.

The air quality and the thermal environment inside the spaces are directly influenced by the level of occupancy. Table 1 shows the occupation cycle during a working day in some of the occupied spaces during the use of the library between 9:00 and 20:00. This information was recorded over several random working days of the various months of the year. The daily average values of the seated occupants in each of the defined daytime periods were considered. The spaces presented in Table 1 
were those considered as representative in the numerical simulation. However, it should be noted that all spaces were evaluated.

Table 1. Occupation cycle during a working day when the library was in use.

\begin{tabular}{ccccc}
\hline \multirow{2}{*}{ Room Number } & \multicolumn{4}{c}{ Timetable } \\
\cline { 2 - 5 } & $\mathbf{9 : 0 0}$ to 13:00 & $\mathbf{1 3 : 0 0}$ to $\mathbf{1 4 : 0 0}$ & $\mathbf{1 4 : 0 0}$ to $\mathbf{1 7 : 0 0}$ & $\mathbf{1 7 : 0 0}$ to 20:00 \\
\hline 16 & 1 & 0 & 2 & 2 \\
19 & 1 & 1 & 1 & 1 \\
35 & 3 & 0 & 4 & 3 \\
37 & 3 & 0 & 2 & 4 \\
42 & 3 & 0 & 4 & 2 \\
47 & 1 & 1 & 3 & 3 \\
52 & 15 & 20 & 60 & 80 \\
58 & 4 & 6 & 2 & 2 \\
81,90 & 2 & 1 & 4 & 3 \\
106 & 2 & 1 & 3 & 4 \\
111 & 3 & 0 & 2 & 4 \\
129 & 2 & & & 2 \\
\hline
\end{tabular}

The expected personal activity in a typical library room is represented by a metabolic rate of $1.2 \mathrm{met}\left(70 \mathrm{~W} / \mathrm{m}^{2}\right)$ [27]. The clothing insulation level considered is $1.0 \mathrm{clo}\left(0.155 \mathrm{~m}^{2}{ }^{\circ} \mathrm{C} / \mathrm{W}\right)$ for a typical winter day, and 0.5 clo $\left(0.078 \mathrm{~m}^{2}{ }^{\circ} \mathrm{C} / \mathrm{W}\right)$ for a typical summer day [27].

Here, the ventilation strategy was to consider the possibility of obtaining an air change rate between 0.5 to 8 . The lowest values were associated with natural air infiltration, while the highest values were achieved by cross-ventilation, for example opening windows $[31,66,67]$. Regarding both situations, the airflow came from the outside to the inside through the windows.

\section{Results and Discussion}

The long-term thermal comfort conditions (warm and cold uncomfortable hours), the long-term indoor air quality conditions (uncomfortable hours due to indoor air quality), the thermal comfort level (PMV index) and the indoor air quality (carbon dioxide concentration) for the different rooms and for different air change rates, for both summer and winter conditions, were evaluated to achieve a more energy-efficient and sustainable building without compromising the occupants' thermal comfort level and indoor air quality.

\subsection{Long-Term Conditions}

The long-term conditions can be evaluated by the total number of uncomfortable hours (UH), obtained during a year (see Figure 3). Equation (4) shows that the total number of uncomfortable hours is obtained using the sum of the warm uncomfortable hours (WUH), the cold uncomfortable hours (CUH) and the uncomfortable hours due to indoor air quality (AQUH) for each air change rate, considered between 0.5 to 8 per hour. The lowest value is obtained by air infiltration and the highest value can be obtained with the windows and door open [37,38].

The evolution of the annual total of WUH, CUH, TUH, AQUH and $\mathrm{UH}$ as a function of the air change rate are presented in Figure 3, while in Figure 4, the evolutions of each monthly total of UH as a function of the air change rate are presented. 


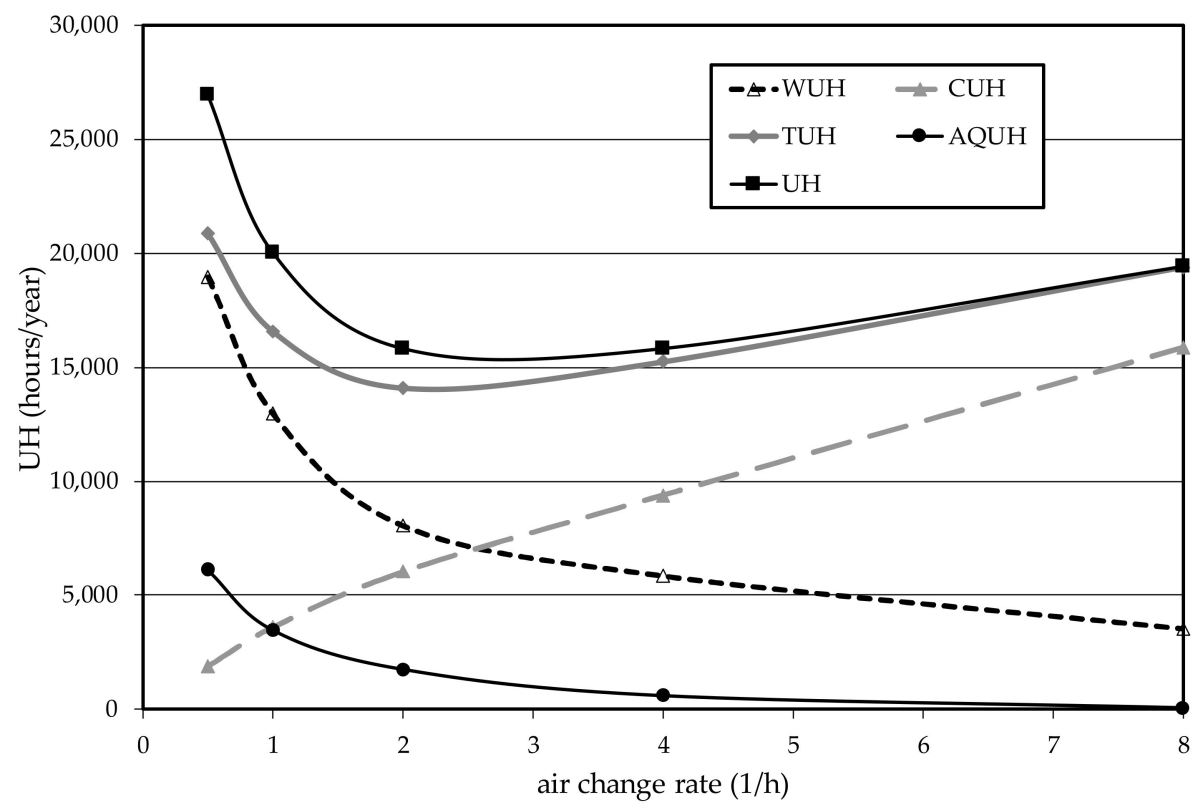

Figure 3. Evolutions of the annual total of Warm Uncomfortable Hours (WUH), Cold Uncomfortable Hours (CUH), Thermal Uncomfortable Hours (THU), Air Quality Uncomfortable Hours (AQUH) and Uncomfortable Hours (UH) in function of the air change rate.

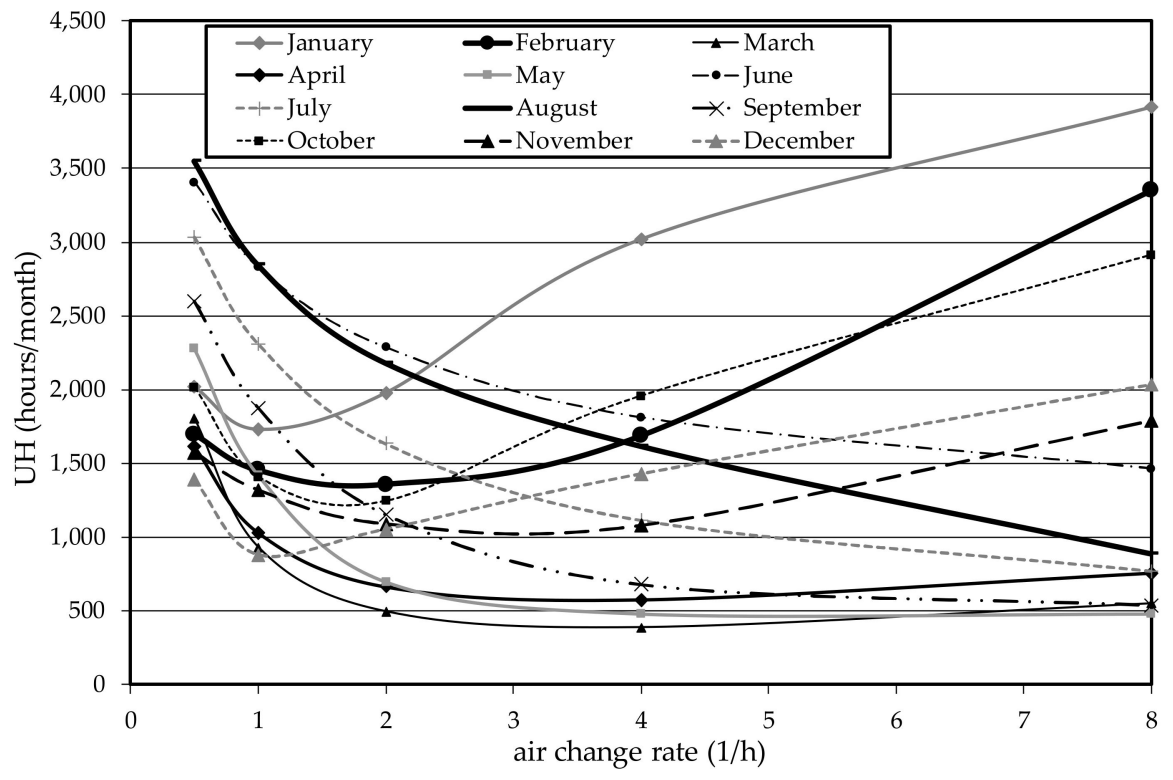

Figure 4. Evolutions of each monthly total of Uncomfortable Hours (UH) in the function of the air change rate.

According to the results presented in Figure 3, it is possible to define an air exchange rate which minimizes the total number of uncomfortable hours. These hours are identified when the limits for acceptable thermal comfort (category C of ISO 7730 [27]) and/or the limit for acceptable indoor air quality $\left(\mathrm{CO}_{2}\right.$ concentration of 1000 ppm [48]) are exceeded. Figure 3 shows an air change rate of around three, where the air exchange rate is the value that represents the minimum number of uncomfortable hours during a year. According the results presented in Figure 3, when the air change rate increases, the number of cold uncomfortable hours increases, the number of warm uncomfortable hours decreases and the number of uncomfortable hours due to indoor air quality also decreases.

To ascertain whether this value is appropriate to the different weather conditions throughout the year, a more detailed study was carried out for each month of the year, and the results are presented in 
Figure 4. According to these results, it is possible to define an air change rate for a minimum total number of uncomfortable hours for each month of the year. Thus, it is possible to define the most appropriate ventilation strategy for each month of the year.

When the air change rate increases in summer conditions (see Figure 4), the total number of uncomfortable hours decreases because the number of warm uncomfortable hours decreases and the number of uncomfortable hours due to indoor air quality also decreases. Thus, in summer conditions, three air change rates was used, because this is the air change rate value that minimizes the total number of uncomfortable hours during a year (see Figure 3).

It is verified that, with the increase of the air change rate in winter conditions, the indoor air quality increases [37] with the decrease of the number of uncomfortable hours due to indoor air quality, and the thermal comfort level decreases with the increase of the number of cold uncomfortable hours. Thus, in this study, an air change rate of two is used in winter conditions, obtained with the average air change rate of the winter months.

These results can be generalized to similar buildings, with similar occupation levels and located in similar Mediterranean-type climates. However, the new methodology developed in this paper can be applied in other buildings with different designs and located in other sorts of climates, adopting new and more acceptable limits for thermal comfort (difference of category $\mathrm{C}$ [27]) and $\mathrm{CO}_{2}$ concentration (difference of 1000 ppm [48]).

This new methodology can be useful for optimizing building ventilation systems by setting the appropriate flow rates for different months of the year and comparing the operability of different ventilation systems. Additionally, it also provides a benchmark for the integral performance of different buildings with regard to their indoor air quality and thermal comfort levels.

\subsection{Thermal Comfort Evaluation by PMV Index}

This section presents the evaluation of the PMV index in 13 compartments (numbered as 16, 19, $35,37,42,46,52,58,81,90,106,111$ and 129) distributed over the 3 floors and selected because their thermal responses were representative of most of the other building compartments.

These compartments have windows that received incident solar radiation from several orientations. The evaluation of the PMV index was obtained for an air change rate of two per hour (best option) in a typical winter condition and for an air change rate of three per hour (best option) in a typical summer condition. The calculated PMV index is shown in Figure 5 for winter conditions and in Figure 6 for summer conditions.

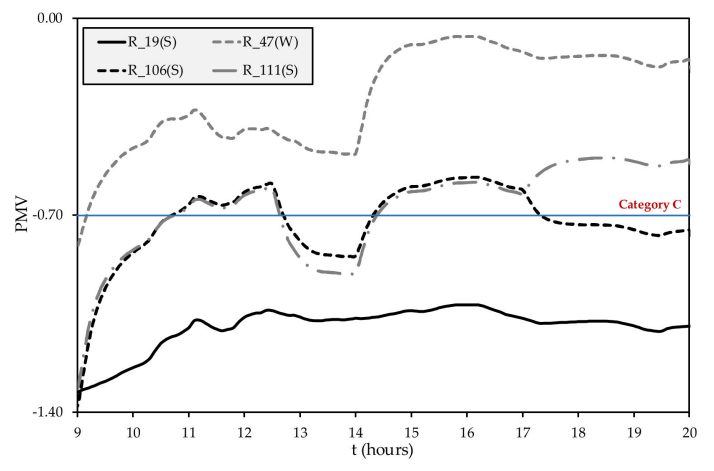

(a)

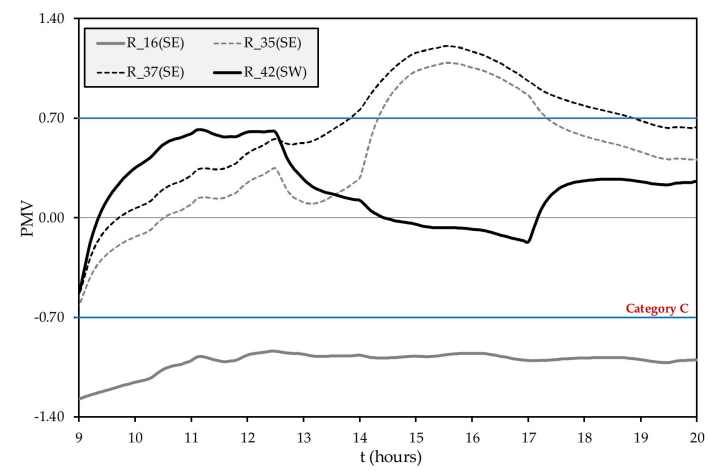

(b)

Figure 5. Cont. 


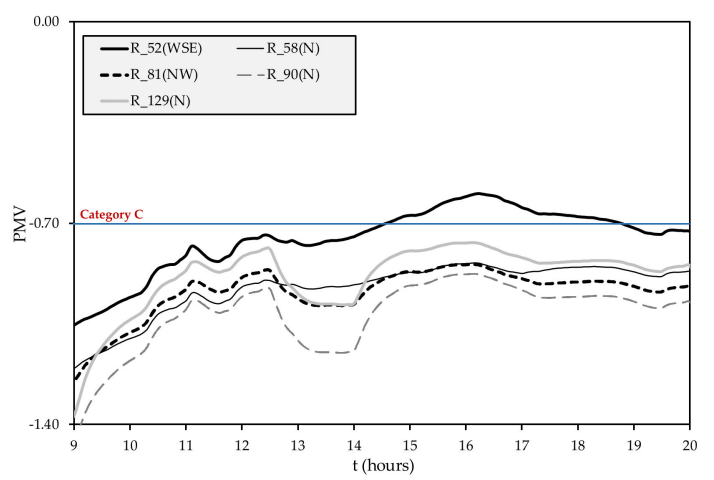

(c)

Figure 5. PMV index evolution for a typical winter day for an air change rate of two renewals per hour: (a) Rooms 19, 47, 106 and 111; (b) Rooms 16, 35, 37 and 42; (c) Rooms 52, 58, 81, 90 and 129. N, S, E, W, SE, SW, NW and WSE, presented in the legend, are associated with the windows facing, respectively North, South, East, West, Southeast, Southwest, Northwest and West-South-East directions.

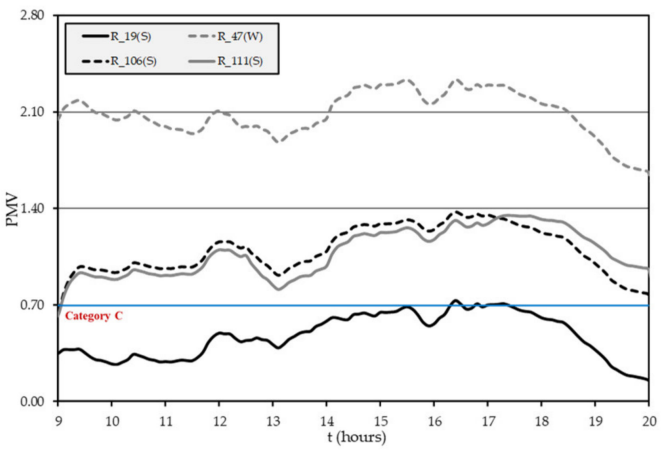

(a)

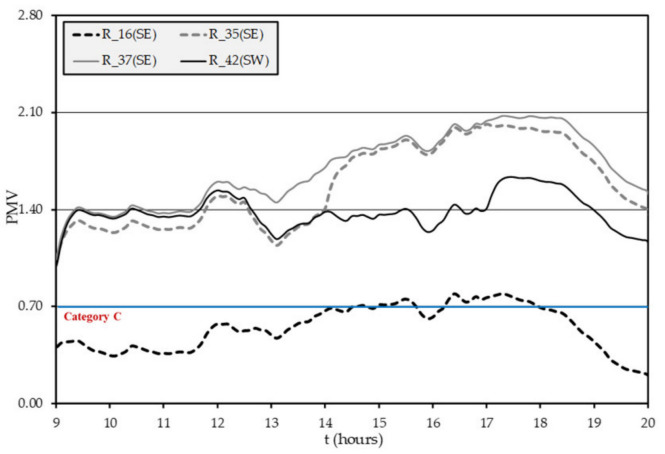

(b)

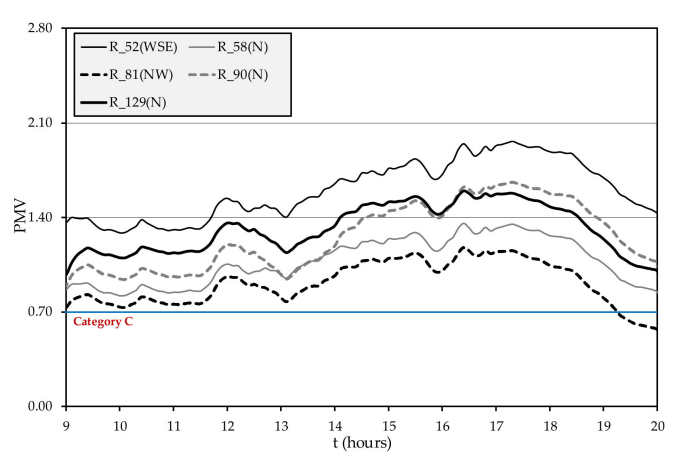

(c)

Figure 6. PMV index evolution for a typical summer day for an air change rate of three renewals per hour: (a) Rooms 19, 47, 106 and 111; (b) Rooms 16, 35, 37 and 42; (c) Rooms 52, 58, 81, 90 and 129. N, S, E, W, SE, SW, NW and WSE, presented in the legend, are associated with the windows facing, respectively North, South, East, West, Southeast, Southwest, Northwest and West-South-East directions.

Figures 5 and 6 show N, S, E, W, SE, SW, NW and WSE, presented in the legend, are associated with the windows facing, respectively North, South, East, West, Southeast, Southwest, Northwest and West-South-East directions. Figures 5 and 6 have the blue line represent the limits of PMV within category C [27].

According to the PMV index results obtained for winter conditions (two air change rates) it is possible to conclude that:

- The rooms facing north (for example, rooms 58 and 90) and the rooms facing west (for example, room 47) were uncomfortable due to negative PMV index values according to category C [27]; 
- The rooms facing south (for example, room 19) generally were slightly uncomfortable due to the negative PMV index values according to category C [27]; room 111 is an example of a room facing south that was comfortable in the afternoon with negative PMV values according to category C [27], but uncomfortable in the morning; however, room 106 is an example of a room facing south with PMV values varying slightly around the lower limit of category C [27];

- The rooms facing southwest (for example, room 42) were comfortable, due to positive PMV index values according to category C [27];

- The rooms facing southeast (for example, room 16) were generally comfortable due to positive PMV index values according to category C [27];

- The main hall (room 52) was uncomfortable due to negative PMV index values, according to category C [27].

According to the PMV index results obtained for summer conditions (three air change rates) it is possible to conclude that:

- Almost all rooms facing south, southeast, southwest and west were uncomfortable due to positive PMV index values according to category C [27], except a few rooms (for example, rooms 19 and 35) which were comfortable almost all day due to the positive PMV index values according to category C [27];

- $\quad$ The rooms facing north (for example, rooms 58 and 90) and northwest (for example, room 81) were uncomfortable due to the positive PMV index values according to category C [27];

- The main hall (room 52) was uncomfortable all day due to the positive PMV index values according to category C [27].

Taking into account the passive solution implemented, mainly in winter conditions, the use of solar radiation, as an energy efficient solution, promotes a good thermal comfort level for the occupants of buildings located in southern Portugal. Concerning a large glazing surface, it is difficult to guarantee a good level of thermal comfort for the occupants due to the high values of solar radiation existing mainly in the summer conditions in southern Portugal. The application of only cross ventilation systems, mainly in summer conditions, is also difficult for cooling the compartments to acceptable thermal comfort levels.

\subsection{Indoor Air Quality Evaluation by $\mathrm{CO}_{2}$ Concentration}

This section presents the evolution of the $\mathrm{CO}_{2}$ concentration in the same compartments where the evaluation of the PMV index is presented. The evaluation of the $\mathrm{CO}_{2}$ concentration is obtained for an air change rate of two per hour (best option) in typical winter conditions and for an air change rate of three per hour (best option) in typical summer conditions. The evaluation of the $\mathrm{CO}_{2}$ concentration can be seen in Figure 7 for winter conditions and in Figure 8 for summer conditions.

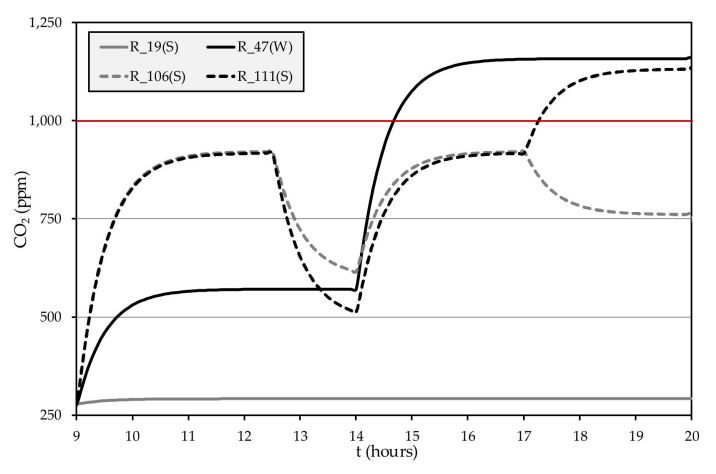

(a)

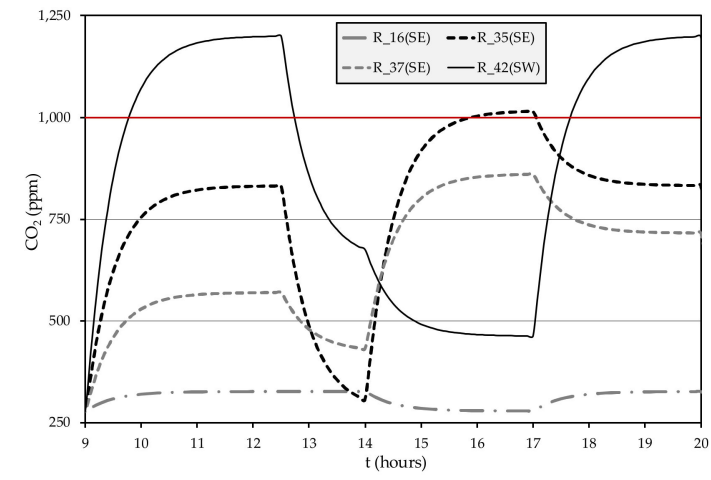

(b)

Figure 7. Cont. 


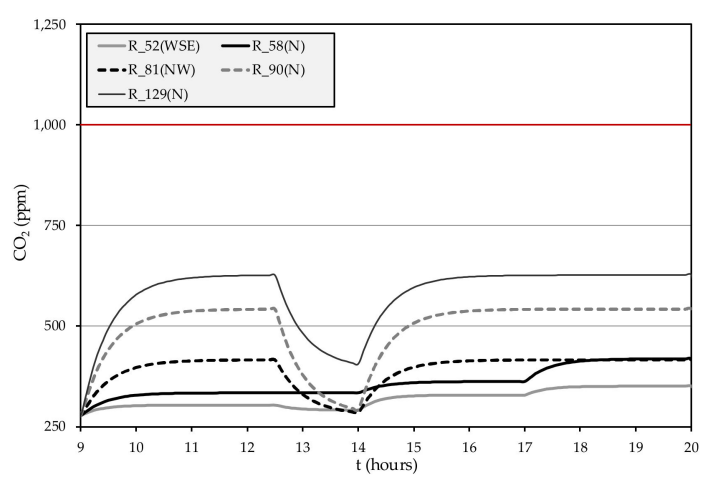

(c)

Figure 7. $\mathrm{CO}_{2}$ concentration evolution for a typical winter day for an air change rate of two renewals per hour: (a) Rooms 19, 47, 106 and 111; (b) Rooms 16, 35, 37 and 42; (c) Rooms 52, 58, 81, 90 and 129. N, S, E, W, SE, SW, NW and WSE, presented in the legend, are associated with the windows facing, respectively North, South, East, West, Southeast, Southwest, Northwest and West-South-East directions.

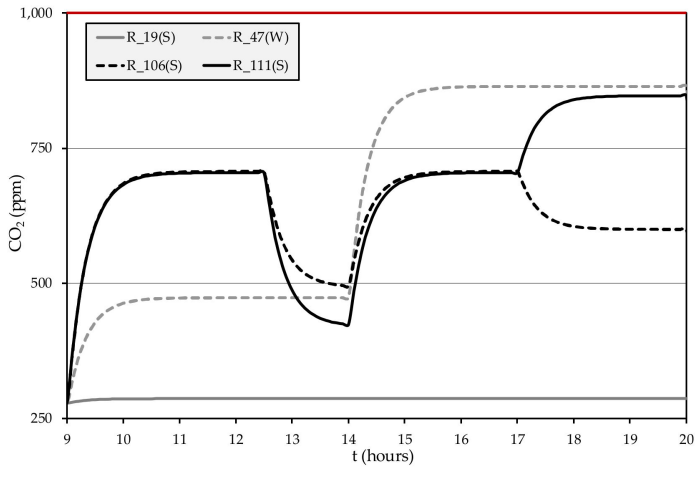

(a)

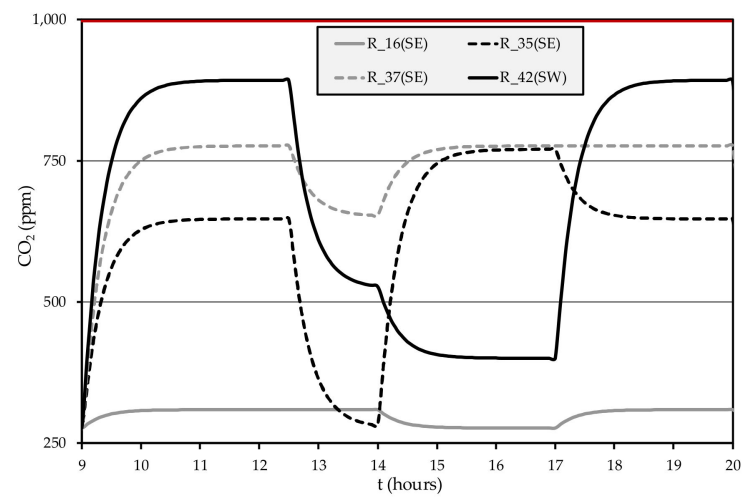

(b)

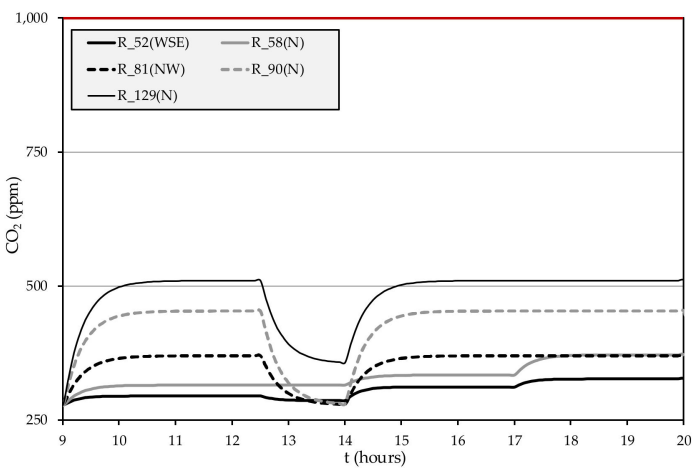

(c)

Figure 8. $\mathrm{CO}_{2}$ concentration evolution for a typical summer day for an air change rate of three renewals per hour: (a) Rooms 19, 47, 106 and 111; (b) Rooms 16, 35, 37 and 42; (c) Rooms 52, 58, 81, 90 and 129. N, S, E, W, SE, SW, NW and WSE, presented in the legend, are associated with the windows facing, respectively North, South, East, West, Southeast, Southwest, Northwest and West-South-East directions.

Figures 7 and 8, using N, S, E, W, SE, SW, NW and WSE presented in the legend, are associated with the windows facing, respectively, North, South, East, West, Southeast, Southwest, Northwest and West-South-East directions. Figures 7 and 8 have the brown line represent the acceptable limit of $\mathrm{CO}_{2}$ concentration [48].

According to the $\mathrm{CO}_{2}$ concentration results obtained for winter conditions (two air change rates) it is possible to conclude that: 
- All rooms with dimensions and occupancy rates similar to rooms 16, 19, 35, 58, 90 and 106 had an acceptable indoor air quality level all day, with values below $1000 \mathrm{ppm}$ [48];

- The rooms, with small dimensions and occupancy rates, such as room 42 had an undesirable indoor air quality level in the morning and at the end of the afternoon, while rooms like 47 had an undesirable indoor air quality level in the afternoon and rooms like $111 \mathrm{had}$ an undesirable indoor air quality level (values above 1000 ppm [48]) at the end of the afternoon. During these periods, in winter conditions, the air change rate was not sufficient to adequately ventilate these types of rooms;

- The main hall (room 52) had a good indoor air quality level all day due to its large dimensions.

According to the $\mathrm{CO}_{2}$ concentration results obtained for summer conditions (three air change rates), it is possible to conclude that all rooms, including room 52 , had an acceptable indoor air quality level all day, due to the availability of an adequate ventilation rate.

\section{Conclusions}

The influence of the airflow into a solar passive building on the indoor air quality and thermal comfort levels was numerically investigated. The purpose was to implement a low energy consumption solution that provided both good thermal comfort and indoor air quality levels for the building occupants.

During this numerical study, the thermal comfort was assessed by the PMV index and the indoor air quality was assessed by the concentration of $\mathrm{CO}_{2}$ for the building occupants. To evaluate the airflow rate that provided both the best thermal comfort and indoor air quality levels, a new methodology that considered an integral model based on the minimization of the total number of uncomfortable hours due to thermal comfort and indoor air quality was applied.

Based on the monthly total number of uncomfortable hours it was possible to determine an air change rate that ensured a good compromise between thermal comfort and indoor air quality levels for the occupants of the building. Regarding winter conditions, an optimum two air change rates was obtained and for summer conditions the optimal air change rate was three. These ventilation rates were obtained using cross-ventilation strategies. Consequently, the use of HVAC systems can be avoided and the energy consumption of the building reduced.

Using the calculated ventilation rates, the levels of thermal comfort and indoor air quality of all building compartments were evaluated. The results showed that most compartments had thermal comfort levels within or very close to category C [27], both in winter and summer conditions. However, in summer conditions it was more difficult to ensure adequate thermal comfort levels due to the large glazed surfaces and consequent exposure to high levels of incident solar radiation. The air ventilation rates obtained were able to provide acceptable indoor air quality levels all the working day, below the recommended $\mathrm{CO}_{2}$ concentration value of $1000 \mathrm{ppm}$ [48], both in winter and summer conditions.

This new methodology can be applied to other buildings with different designs and occupation levels and located in other climates, adapting the most suitable acceptable limits for thermal comfort and $\mathrm{CO}_{2}$ concentration.

Concerning future works, this new numerical methodology, applied in solar passive buildings, will be used with the coupling of the human thermal physiology numerical model. The coupling of these two numerical software can be used to evaluate, in detail and simultaneously, the thermal comfort level to which each occupant of an indoor building space is subjected. This philosophy will be applicable to this modern library and to other solar passive buildings to use these passive and active solar strategies to guarantee simultaneous thermal comfort levels for most occupants.

Author Contributions: Investigation, E.C., J.G. and H.A.

Funding: This research received no external funding. 
Acknowledgments: The authors would like to acknowledge to the project (SAICT-ALG/39586/2018) from Algarve Regional Operational Program (CRESC Algarve 2020), under the PORTUGAL 2020 Partnership Agreement, through the European Regional Development Fund (ERDF) and the National Science and Technology Foundation (FCT).

Conflicts of Interest: The authors declare no conflict of interest.

\section{References}

1. Intergovernmental Panel on Climate Change. Global Warming of $1.5^{\circ} \mathrm{C}$. Available online: https://report.ipcc. ch/sr15/pdf/sr15_spm_final.pdf (accessed on 20 September 2019).

2. International Energy Agency. $\mathrm{CO}_{2}$ Emissions Statistics. Available online: https://www.iea.org/statistics/ co2emissions/ (accessed on 20 September 2019).

3. European Commission. Energy Use in Buildings. Available online: https://ec.europa.eu/energy/en/eubuildings-factsheets-topics-tree/energy-use-buildings (accessed on 22 September 2019).

4. WGBC. WORLD GREEN BUILDING COUNCIL Annual Report 2015/2016. Available online: http://www. worldgbc.org/sites/default/files/P578WGBCAnnualReport_LR4.pdf (accessed on 17 August 2019).

5. Khan, S.; Zakaria, R.; Shamsudin, S.; Abidin, N.; Sahamir, S.; Abbas, D.; Aminudin, E. Evolution to emergence of green buildings: A review. Adm. Sci. 2019, 9, 6. [CrossRef]

6. Zhang, C.; Cui, C.; Zhang, Y.; Yuan, J.; Luo, Y.; Gang, W. A review of renewable energy assessment methods in green building and green neighborhood rating systems. Energy Build. 2019, 195, 68-81. [CrossRef]

7. Ahmad, T.; Aibinu, A.; Stephan, A. Managing green building development-A review of current state of research and future directions. Build. Environ. 2019, 155, 83-104. [CrossRef]

8. Illankoon, I.; Tam, V.; Le, K.; Shen, L. Key credit criteria among international green building rating tools. J. Clean. Prod. 2017, 164, 209-220. [CrossRef]

9. Gou, Z.; Xie, X. Evolving green building: Triple bottom line or regenerative design? J. Clean. Prod. 2017, 153, 600-607. [CrossRef]

10. Lu, S.; Fan, M.; Zhao, Y. A system to pre-evaluate the suitability of energy-saving technology for green buildings. Sustainability 2018, 10, 3777. [CrossRef]

11. Persily, A.; Emmerich, S. Indoor air quality in sustainable, energy efficient buildings. HVACR Res. 2012, 18, 4-20.

12. Peuportier, B.; Thiers, S.; Guiavarch, A. Eco-design of buildings using thermal simulation and life cycle assessment. J. Clean. Prod. 2013, 39, 73-78. [CrossRef]

13. Sun, B.; Luh, P.; Jia, Q.; Jiang, Z.; Wang, F.; Song, C. Building energy management: Integrated control of active and passive heating, cooling, lighting, shading, and ventilation systems. IEEE Trans. Autom. Sci. Eng. 2013, 10, 588-602.

14. Mattoni, B.; Guattari, C.; Evangelisti, L.; Bisegna, F.; Gori, P.; Asdrubali, F. Critical review and methodological approach to evaluate the differences among international green building rating tools. Renew. Sustain. Energy Rev. 2018, 82, 950-960. [CrossRef]

15. Wang, J.; Pan, W. Influencing parameters of the life cycle cost energy relationship of buildings. J. Green Build. 2018, 13, 103-121. [CrossRef]

16. U.S. Environmental Protection Agency. Green Buildings. Available online: https://www.epa.gov/landrevitalization/green-buildings (accessed on 24 September 2019).

17. Chandratilake, S.; Dias, W. Sustainability rating systems for buildings: Comparisons and correlations. Energy 2013, 59, 22-28. [CrossRef]

18. Ding, Z.; Fan, Z.; Tam, V.; Bian, Y.; Li, S.; Illankoon, I.; Moon, S. Green building evaluation system implementation. Build. Environ. 2018, 133, 32-40. [CrossRef]

19. Geng, Y.; Ji, W.; Wang, Z.; Lin, B.; Zhu, Y. A review of operating performance in green buildings: Energy use, indoor environmental quality and occupant satisfaction. Energy Build. 2019, 183, 500-514. [CrossRef]

20. Olubunmi, O.; Xia, P.; Skitmore, M. Green building incentives: A review. Renew. Sustain. Energy Rev. 2016, 59, 1611-1621. [CrossRef]

21. Goyal, S.; Ingley, H.; Barooah, P. Occupancy-based zone-climate control for energy efficient buildings: Complexity vs. performance. Appl. Energy 2013, 106, 209-221. [CrossRef] 
22. Lazzerini, R.; Curtis, D.; Bowen, R.; Patel, M.; Ruscisa, G.; Lazzerini, P.; Renzio, M.; Zabot, S.; Guarino, D.; Cellie, A. ANNEX XV-Energy Efficiency in Schools. Part One; IEA-International Energy Agency: Paris, France, 1991.

23. Lazzerini, R.; Curtis, D.; Bowen, R.; Patel, M.; Ruscisa, G.; Lazzerini, P.; Renzio, M.; Zabot, S.; Guarino, D.; Cellie, A. ANNEX XV-Energy Efficiency in Schools. Part Two; IEA-International Energy Agency: Paris, France, 1991.

24. Howell, R.; Land, D. Air-cooled HVAC retrofit: Safe bet for Vegas schools. ASHRAE J. 2004, 46, $28-34$.

25. Warden, D. Dual fan, dual duct goes to school. ASHRAE J. 2004, 46, $18-27$.

26. Fanger, P. Thermal Comfort: Analysis and Applications in Environmental Engineering; Danish Technical Press: Copenhagen, Denmark, 1970.

27. ISO 7730. Ergonomics of the Thermal Environments-Analytical Determination and Interpretation of Thermal Comfort Using Calculation of the PMV and PPD Indices and Local Thermal Comfort Criteria; International Standard Organization: Geneva, Switzerland, 2005.

28. ANSI/ASHRAE Standard 55. Thermal Environmental Conditions for Human Occupancy; American Society of Heating, Refrigerating and Air-Conditioning Engineers: Atlanta, GA, USA, 2013.

29. Ayata, T.; Yildiz, O. Investigating the potential use of natural ventilation in new building designs in Turkey. Energy Build. 2006, 38, 959-963. [CrossRef]

30. Wang, L.; Dols, W.; Emmerich, S. Simultaneous solutions of coupled thermal flow problem for natural ventilation in buildings. HVACR Res. 2012, 18, 264-274.

31. Schulze, T.; Eicker, U. Controlled natural ventilation for energy efficient buildings. Energy Build. 2013, 53, 221-232. [CrossRef]

32. Hamzah, B.; Gou, Z.; Mulyadi, R.; Amin, S. Thermal comfort analyses of secondary school students in the tropics. Buildings 2018, 8, 56. [CrossRef]

33. Stavakrakis, G.; Koukou, M.; Vrachopoulos, M.; Markatos, N. Natural cross-ventilation in buildings: Building-scale experiments, numerical simulations and thermal comfort evaluation. Energy Build. 2008, 40, 1666-1681. [CrossRef]

34. Mochida, A.; Yoshino, H.; Takeda, T.; Kakegawa, T.; Myauchi, S. Methods for controlling airflow in and around a building under cross-ventilation to improve indoor thermal comfort. J. Wind Eng. Ind. Aerodyn. 2005, 93, 437-449. [CrossRef]

35. Raja, I.; Nicol, J.; McCartney, K.; Humphreys, M. Thermal comfort: Use of controls in natural ventilated buildings. Energy Build. 2001, 33, 235-244. [CrossRef]

36. Gallardo, A.; Palme, M.; Lobato-Cordero, A.; Béltran, R.; Gaona, G. Evaluating thermal comfort in a naturally conditioned office in a temperate climate zone. Buildings 2016, 6, 27. [CrossRef]

37. Conceição, E.; Lúcio, M.; Vicente, V.; Rosão, V. Evaluation of local thermal discomfort in a classroom equipped with crossed ventilation. Int. J. Vent. 2008, 3, 267-277. [CrossRef]

38. Conceição, E.; Gomes, J.; Antão, N.; Lúcio, M. Application of a developed adaptive model in the evaluation of thermal comfort in ventilated kindergarten occupied spaces. Build. Environ. 2012, 50, 190-201. [CrossRef]

39. Olesen, B.; Parsons, K. Introduction to thermal comfort standards and to the proposed new version of EN ISO 7730. Energy Build. 2002, 34, 537-548. [CrossRef]

40. Van der Linden, K.; Boerstra, A.; Raue, A.; Kurvers, S. Thermal indoor climate building performance characterized by human comfort response. Energy Build. 2002, 34, 737-744. [CrossRef]

41. Spiru, P.; Simona, P. A review on interactions between energy performance of the buildings, outdoor air pollution and the indoor air quality. Energy Procedia 2017, 128, 179-186. [CrossRef]

42. Vornanen-Winqvist, C.; Salonen, H.; Järvi, K.; Andersson, M.; Mikkola, R.; Marik, T.; Kredics, L.; Kurnitski, J. Effects of ventilation improvement on measured and perceived indoor air quality in a school building with a hybrid ventilation system. Int. J. Environ. Res. Public Health 2018, 15, 1414. [CrossRef] [PubMed]

43. Asere, L.; Blumberga, A. Energy efficiency_Indoor air quality dilemma in public buildings. Energy Procedia 2017, 147, 445-451. [CrossRef]

44. Asif, A.; Zeeshan, M.; Jahanzaib, M. Indoor temperature, relative humidity and $\mathrm{CO}_{2}$ levels assessment in academic buildings with different heating, ventilation and air-conditioning systems. Build. Environ. 2018, 133, 83-90. [CrossRef]

45. Kelly, F.; Fussel, J. Improving indoor air quality, health and performance within environments where people live, travel, learn and work. Atmos. Environ. 2019, 200, 90-109. [CrossRef] 
46. Laverge, J.; Van Den Bossche, N.; Heijmans, N.; Janssens, A. Energy saving potential and repercussions on indoor air quality of demand controlled residential ventilation strategies. Build. Environ. 2011, 46, 1497-1503. [CrossRef]

47. Fanger, P. Introduction of the olf and decipol unit to quantify air-pollution perceived by humans indoors and outdoors. Energy Build. 1988, 12, 1-6. [CrossRef]

48. ANSI/ASHRAE Standard 62-1. Ventilation for Acceptable Indoor Air Quality; American Society of Heating, Refrigerating and Air-Conditioning Engineers: Atlanta, GA, USA, 2016.

49. Persily, A.; de Jonge, L. Carbon dioxide generation rates for buildings occupants. Indoor Air 2017, 27, 868-879. [CrossRef]

50. Mujan, I.; Andelkovic, A.; Muncan, V.; Kljajic, M.; Ruzic, D. Influence of indoor environmental quality on human health and productivity-A review. J. Clean. Prod. 2019, 217, 646-657. [CrossRef]

51. Lotfabadi, P. Analyzing passive solar strategies in the case of high-rise building. Renew. Sustain. Energy Rev. 2015, 52, 1340-1353. [CrossRef]

52. Okeil, A. A holistic approach to energy efficient building forms. Energy Build. 2010, 42, 1437-1444. [CrossRef]

53. Nanda, A.; Panigrahi, C. A state-of-the-art review of solar passive building system for heating or cooling purpose. Front. Energy 2016, 10, 347-354. [CrossRef]

54. Bournas, I.; Abugabbara, M.; Balcerzak, A.; Dubois, M.; Javed, S. Energy renovation of an office building using a holistic design approach. J. Build. Eng. 2016, 7, 194-206. [CrossRef]

55. Zeiler, W.; Gvozdenovic, K.; de Bont, K.; Maassen, W. Toward cost-effective nearly zero energy buildings: The Dutch Situation. Sci. Technol. Built Environ. 2016, 22, 911-927. [CrossRef]

56. Congedo, P.; Baglivo, C.; D’Agostino, D.; Zaca, I. Cost-optimal design for nearly zero energy office buildings located in warm climates. Energy 2015, 91, 967-982. [CrossRef]

57. Saadatian, O.; Sopian, K.; Lim, C.; Asim, N. Trombe walls: A review of opportunities and challenges in research and development. Renew. Sustain. Energy Rev. 2012, 16, 6340-6351. [CrossRef]

58. Conceição, E.; Lúcio, M. Numerical study of the thermal efficiency of a school building with complex topology for different orientations. Indoor Built Environ. 2009, 18, 41-51. [CrossRef]

59. Conceição, E.; Lúcio, M. Numerical simulation of passive and active solar strategies in buildings with complex topology. Build. Simul. 2010, 3, 245-261. [CrossRef]

60. Cheng, Y.; Zhang, S.; Huan, C.; Oladokun, M.; Lin, Z. Optimization on fresh outdoor air ratio of air conditioning system with stratum ventilation for both targeted indoor air quality and maximal energy savings. Build. Environ. 2019, 147, 11-22. [CrossRef]

61. Conceição, E.; Silva, A.; Lúcio, M. Numerical Study of Thermal Response of School Buildings in Winter Conditions. In Proceedings of the 9th Conference on Air Distribution in Rooms (Roomvent 2004), Coimbra, Portugal, 5-8 September 2004.

62. Conceição, E.; Lúcio, M. Numerical Study of Thermal Response of School Buildings in Summer Conditions. In Proceedings of the 8th International Conference and Exhibition on Healthy Buildings (HB 2006), Lisbon, Portugal, 4-8 June 2006.

63. Conceição, E.; Nunes, A.; Gomes, J.; Lúcio, M. Application of a school building thermal response numerical model in the evolution of the adaptive thermal comfort in the Mediterranean environment. Int. J. Vent. 2010, 9, 287-304. [CrossRef]

64. Conceição, E.; Gomes, J.; Ruano, A. Application of HVAC systems with control based on PMV index in university buildings with complex topology. IFAC PapersOnLine 2018, 51, 20-25.

65. Conceição, E.; Sousa, A.; Gomes, J.; Ruano, A. HVAC systems applied in university buildings with control based on PMV and aPMV indexes. Inventions 2019, 4, 3. [CrossRef]

66. Raja, I.; Nicol, J.; McCartney, K. Thermal comfort: Use of controls in natural ventilated buildings. Renew. Energy 1998, 15, 391-394. [CrossRef]

67. Mochida, A.; Yoshino, H.; Myauchi, S.; Mitamura, T. Total analysis of cooling effects of cross-ventilation affected by microclimate around a building. Sol. Energy 2006, 80, 371-382. [CrossRef]

(C) 2019 by the authors. Licensee MDPI, Basel, Switzerland. This article is an open access article distributed under the terms and conditions of the Creative Commons Attribution (CC BY) license (http://creativecommons.org/licenses/by/4.0/). 